\title{
Foreign Exchange Market Demand Pressure and Economic Growth in Nigeria
}

\author{
DR SAMUEL OMINYI， DR DAVID TERFA AKIGHIR \& MRS. ROSELYNDA ABAYOL- IKWUE \\ DEPARTMENT OF ECONOMICS, BENUE STATE UNIVERSITY MAKURDI-NIGERIA
}

\begin{abstract}
The study has investigated the relationship between foreign exchange market demand pressure and economic growth in Nigeria from 1986 to 2018. The study has used the Marshall-Lerner theory of the demand and supply of foreign exchange. The employed the Autoregressive Distributed Lagged (ARDL) model and Granger Causality test to investigate this relationship. Findings of the study revealed that there exist negative relationships between the foreign exchange market demand pressure and economic growth in both short and long run on the one hand and negative relationship between inflation and economic growth on the other hand both in the short and long run. It was concluded that foreign exchange market demand pressure affects economic growth in Nigeria directly and indirectly via the exchange rate pass-through to domestic prices mechanism. The study recommended that first, the Nigerian economy should be diversified away from oil using the agriculture and manufacturing sectors as articulated in the Economic Growth and Recovery Plan of the Buhari's administration. By diversification, multiple streams of supply of foreign exchange in the economy will be created to close the existing gap between its demand and supply in the country. Also, by diversification of the economy, the demand for imported goods will reduce. The reduction in the demand for imported goods into the country presupposes reduction in demand for foreign exchange. With this, the scarce foreign exchange can be conserved for only importation of capital goods for onward production of goods and services in the country. Thirdly, the Central Bank should regulate the supply of foreign exchange to only critical sectors of the economy. The activities of the importers should also be checked to avoid cases of over invoicing and under invoicing. These activities generally lead to round-tripping with its adverse consequences on the demand and supply of foreign exchange in the country.

Key Words: Autoregressive Distributed Lagged Model, Economic Growth, Foreign Exchange Market Demand Pressure, Granger Causality Test, Marshall-Lerner theory, Nigeria

DOI: $10.7176 / \mathrm{JESD} / 11-4-22$
\end{abstract}

Publication date: February $29^{\text {th }} 2020$

\section{Introduction}

Demand pressure in the foreign exchange market is related to increase in demand for foreign currency over its supply and depreciation of exchange rate under a flexible exchange rate regime rather than a fixed regime. A country's exchange rate can be put under pressure when the demand for foreign currency exceeds its supply (Central Bank of Nigeria, 2016). The demand for foreign exchange arises in the course of importing goods and services and meeting other payments obligations abroad. In other words, the demand for foreign exchange consists of payments for imports of goods and services, external debt services obligations, personal home remittances by foreign nationals' resident in the country, financial commitments to international organisations and the country's embassies abroad as well as other invisible out payments (Obadan, 2012).

According to the Central Bank of Nigeria (2016), other factors that induce the demand for foreign exchange are the activities of speculators and the Central bank, external interest rate, the current account position, changes in a country's income, monetary and fiscal policies, import dependence, changes in domestic credit, and domestic inflation. A Lot of activities in the foreign exchange market are based on speculation about future events. If the participants believe that there would likely be a devaluation of the local currency by the monetary authorities (Central Banks) for instance, they would buy more foreign exchange today to hedge up the possible risk of losses devaluation would bring to their businesses. 
Journal of Economics and Sustainable Development

ISSN 2222-1700 (Paper) ISSN 2222-2855 (Online)

The Nigerian foreign exchange market has over the years been pressurized. The pressure in the market has had contagious effects on key macroeconomic variables in the country. This has made the Central Bank of Nigeria (CBN) to evolve intervention policies and measures to defend the market and the naira. Some of the recent policies include, the ban of foreign exchange on forty- one items, continuous injection of dollars into the market, currency swap deal, amongst others.

According to Englama, Sanni, Duke, Ogunleye \& Isma'il (2009), the sustained demand pressure in the country has been a major source of currency depreciation and widening premium in the foreign exchange market. The situation has further encouraged speculation, arbitrage activities and the emergence of flourishing parallel market for foreign currency in the country. The premium has created an incentive for authorized dealers to engage in round-tripping of funds from the official sources to the parallel market. As a result, most banks have neglected their core traditional function of intermediation in providing finance to the real sector of the economy and have relied more on foreign exchange trading as a cheap source of generating profit. This disturbing trend has continued to pose serious challenge to the monetary authorities considering the need to ensure an effective management of the foreign reserves of the country and to deploy resources to the productive sectors of the economy.

In Nigeria however, the subject matter of foreign exchange market pressure is rarely investigated though severely experienced in the Nigerian foreign exchange market where demand for foreign exchange often outstrip the its supply. A few studies on the subject have not investigated the effect of demand pressure in the foreign exchange market on economic growth of the Nigerian economy, hence the imperativeness of this study. Thus, the main objective of this study is to investigate empirically the effect of foreign exchange market demand pressure on the economic growth in Nigeria. Towards this end, the paper is structured into five sections following the introductory section. Section two borders on theoretical review, section three is on the empirical literature, section four dwells on the methodology of the study; while section five deals with the empirical data analysis and interpretation of the results and section six considers the conclusion and policy recommendations.

\section{Theoretical Review}

This study is anchored on the Marshall-Lerner demand and supply theory of foreign exchange. This theory was propounded by Alfred Marshall and Abba Lerner to explain how disequilibrium in foreign exchange market can cause devaluation of a country's currency thereby affecting the trade balance of the country. It is commonly referred to as the elasticities approach of balance of trade. It provides an analytical framework of how a currency devaluation will affect the balance of trade depending on the elasticities of supply and demand for foreign exchange and/or foreign goods. The approach stresses exchange rate change for Balance of Payments (BoP) adjustment. In this direction, devaluation of a currency will change the relative prices of domestic and foreign goods which in turn, will change the balance of trade. A devaluation of the naira exchange rate, for example, such that more naira exchange for one U.S dollar, will increase the domestic currency price of foreign goods in Nigeria and reduce the foreign currency price of Nigerian manufactured goods abroad. This relative price of naira devaluation should increase foreign demand for Nigerian exports and reduce Nigeria's demand for foreign goods. However, elasticity of demand will determine how much the quantity demanded changes in response to relative price changes. When demand or supply is elastic, it means that the quantity demanded or supplied will be relatively responsive to change in price. An inelastic demand or supply indicates that the quantity is relatively unresponsive to the price changes. Elasticity will also determine what happens to total export and import revenues following international price 
Journal of Economics and Sustainable Development

ISSN 2222-1700 (Paper) ISSN 2222-2855 (Online)

changes (Crockett, 1987)

Thus, the Marshall-Lerner (M-L) condition states that, given infinite elasticities of supply for exports and imports, and initial trade balance, the sum of the absolute values of the elasticities of demand for exports $\left(e_{X}\right)$ and demand for imports $\left(\left(e_{M}\right)\right.$ should be greater than unity for devaluation to improve the trade balance. In algebraic terms, this translates to:

$$
e_{X}+e_{M}>|-1|
$$

When $e_{X}+e_{M}<|-1|$, a depreciation of currency will make the BoP unfavourable and an appreciation will make

it more favourable. If the sum of $\left(e_{X}\right)$ and $\left(e_{M}\right)$ equals unity, that is,

$$
e_{X}+e_{M}=|-1| \text {, }
$$

A change in the exchange rate will leave the BoP deficit or surplus unchanged. It is only when the Marshall-Lerner condition is satisfied will a change in the exchange rate have its normal effects on BoP, that is, it will improve the BoP of the currency depreciating country and weaken the BoP of the appreciating country.

In terms of the change in the balance of trade, the M-L condition is:

$$
\Delta B=d X\left(e_{X}+e_{M}-1\right)
$$

Where: $\Delta B=$ change in the trade balance, $d=$ rate of devaluation, $X=$ value of exports expressed in foreign

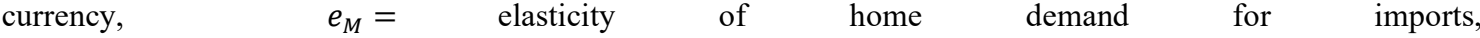
$e_{X}=$ elasticity of foreign demand for home country's exports (Crockett, 1987).

A diagrammatic analysis of the elasticities approach of BoT is given as follows:

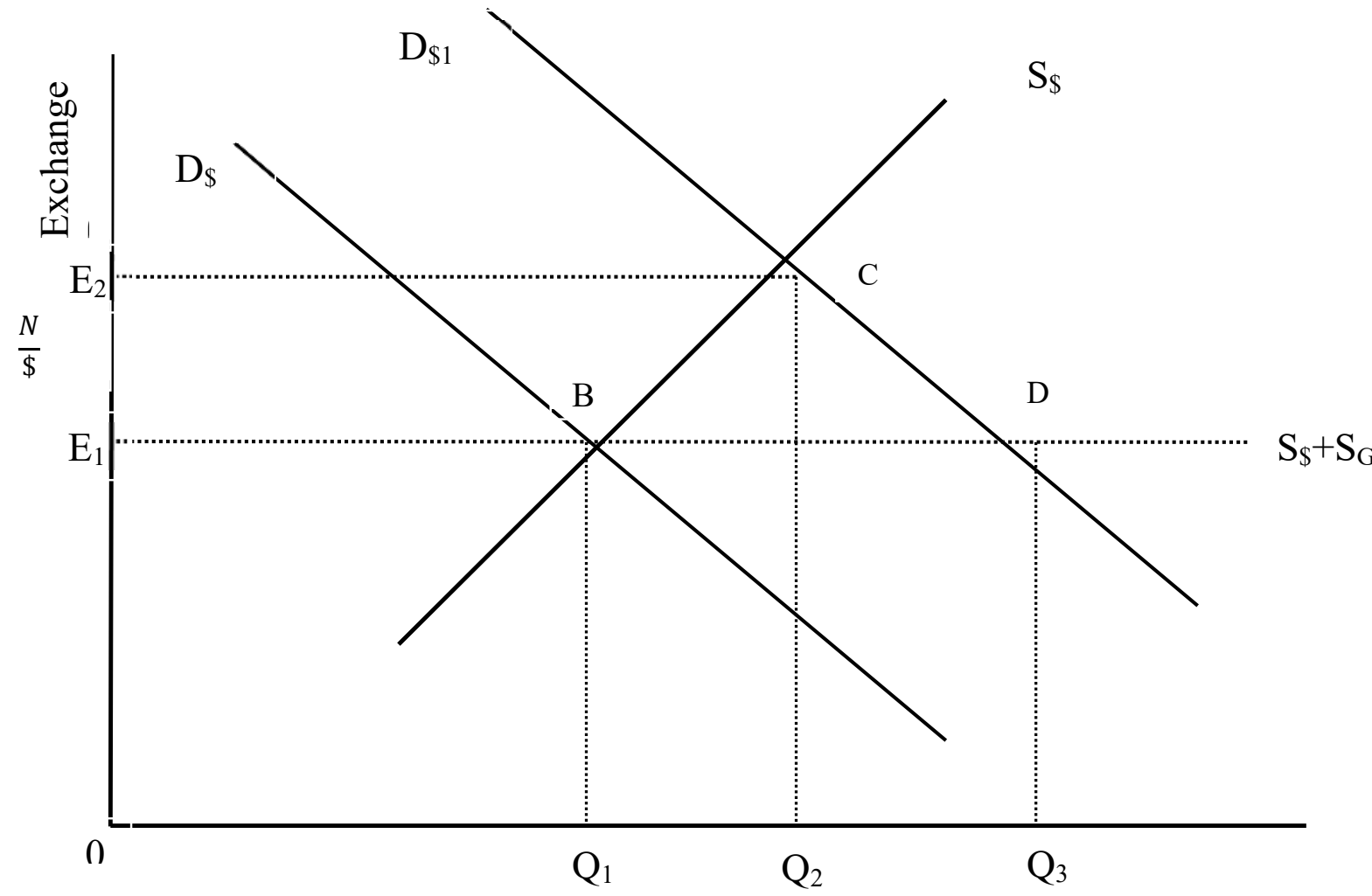

Ouantitv of Dollars in (millions)

Figure 1: Increase in Demand for Foreign Exchange under fixed and floating Exchange Rate 
In this diagram,

$S_{\$}$ represents supply curve of dollars to the foreign exchange market

$D_{\$}$ represents the initial demand curve for dollars while $D_{\$ 1}$ represents a new demand curve for dollars following a change in demand due for example, an increase in demand for foreign exports (demand for imports by Nigerians). The demand curve is downward-sloping indicating that the higher the naira price of dollar, fewer the dollars that will be demanded. On the other hand, the supply curve is upward sloping indicating the familiar positive relationship between price and supply; in this case, the naira price of dollar and the quantity of dollars supplied. Given the initial supply and demand curves, the initial equilibrium is at B where the quantity demanded just equals the supply of dollar $\left(Q_{1}\right)$. The initial exchange rate is $E_{1}$. If there is demand pressure due to increase in Nigerians demand for foreign exports, this will cause the demand curve to shift to $\mathrm{D}_{\$ 1}$. There are a number of possible responses to this shift in demand. These are:

i. The dollar will appreciate (naira depreciates) with freely floating exchange rates so that the exchange rate raises to $\mathrm{E}_{2}$ and $\mathrm{Q}_{1} \mathrm{Q}_{2}$ dollars are bought and sold;

ii. The Central Bank can peg the exchange rate at $\mathrm{E}_{1}$ and provide $\mathrm{Q}_{1} \mathrm{Q}_{3}$ extra dollars $(=\mathrm{CD})$ from its reserves;

iii. Supply and demand curves can be artificially shifted by imposing controls or quotas on the supply of or demand for dollars;

iv. Quotas or tariffs could be imposed on foreign trade to maintain the old supply and demand for dollars; and

v. Monetary policy could change in order to shift curves.

The second response can easily be resorted to where the increase in demand is perceived as transient and the monetary authorities have enough reserves. But where the increase in demand is perceived as a permanent change, then the naira will be devalued, driving up the naira price of the dollar. But whether this will improve the trade balance depends on the elasticities of supply and demand. In this direction, the elasticities approach takes cognizance of the fact that the effects of an exchange rate change on the equilibrium quantity of currency being traded will depend on the elasticities of the supply and demand curves involved (Obadan, 2012).

\section{Empirical Review}

This section has reviewed some empirical literature relating to foreign exchange market and the Nigerian economy. Ailemen, Akhanolu \& Chibuzor (2016) examined deregulation of foreign exchange market and its effect on industrial production in Nigeria. The data for the study were analysed using the ordinary least square (OLS) econometric technique and the results showed that while both labour and capital were positively significant in explaining industrial production in the country, exchange rate and inflation negatively and significantly explained it. In another study, Oladele (2015) investigated the contributions of foreign exchange market to the economic growth of Nigeria from the period of 1996 to 2005 . The analytical tools used to analyse the data were the regression and correlation analyses. The study found that there was a very high positive correlation between the official exchange rate and the gross domestic product (GDP), also between the parallel exchange rate and the gross domestic product (GDP). The two rates jointly determined the movement of the GDP in Nigeria. Based on this, the study recommended that proper management of the foreign exchange should be put in place, since it is a necessary stimulant for economic growth of Nigerian economy.

Furthermore, Fiador \& Nicholas (2015) studied the impact of monetary policy on foreign exchange market pressure evidenced from Sub-Saharan Africa between the period of 1991 to 2010. The study employed a dynamic panel and found a negative and significant relationship between monetary policy and exchange market pressure in these countries.

Also, Akram \& Byme (2015) examined the impact of exchange market pressure on capital controls from 1977 to 2012. The Least Square Dummy Variable (LSDV) was employed and the study found that capital controls are associated with weaker currencies. The study also found that an increase in capital account openness is linked to a reduction in both measures of market pressure. There are two channels through which capital account openness may reduce exchange market pressure. First, market liquidity increases with an increase in international capital flows. An increase in market liquidity in turn accelerates economic growth primarily by boosting productivity growth. Second, the efficiency of the domestic financial sector improves due to the presence of foreign banks, which in turn spurs economic growth.

Oladapo \& Oloyede (2014) examined foreign exchange management and the Nigerian economic growth from 
1970 to 2012. The study employed Ordinary Least Square (OLS) estimation technique within the Error Correction Model (ECM) and also the Johansen-Joselius Co-integration test was employed to test for the presence of a longrun relationship between the dependent variable and independent variables. The study revealed that export is statistically significant in determining economic growth. However, exchange rate, inflation rate and import were found to be statistically non-significant. The study therefore recommended that efforts be made to increase the consumption of made in Nigeria goods in order to increase foreign exchange earnings.

Okosodo \& Imosili (2012) investigated the deregulation of foreign exchange market and its impact on the growth of the Nigerian economy. The Ordinary Least Square (OLS) method was employed and the result revealed that, the deregulation of the foreign exchange market has a direct impact on the growth of the Nigerian economy. Government should therefore, put a machinery in place through the central bank to monitor the valuation of money to curb the trend of inflation in Nigeria.

Akpan (2009) carried out a study on foreign exchange market and economic growth in an emerging petroleum based economy using Nigeria as a case study from 1970 to 2003. The Ordinary Least Square (OLS) technique was adopted. The study found a positive relationship between exchange rate and economic growth in Nigeria, and in view of the findings of the study, it was recommended that exchange rate policy should be designed to bridge the savings investment gap so as to enhance government revenue as well as reduce the fiscal lacuna through the curtailing of deficit geared at increased and sustained economic growth. Gross domestic investment should also be sustained since this leads to significant economic development.

The gap in the empirical literature reviewed is that these studies have not actually considered the foreign exchange market demand pressure and economic growth of the Nigerian economy. Most of the reviewed studies have merely used exchange rate as a measure of foreign exchange market to interact with economic growth and other macroeconomic variables without further efforts to compute the foreign exchange market demand pressure. This apparent gap has necessitated this study which computes foreign exchange market demand pressure as the differential of the demand and the supply of foreign exchange in the Nigerian economy.

\section{Methodology of the Study}

In order to investigate the relationship between foreign exchange market demand pressure and economic growth in Nigeria, the study followed the modelling approach of Rawlins and Praveen (2004). Thus, the implicit function describing the relationship between foreign exchange market demand pressure and economic growth is articulated as:

$$
g d p=f(\text { exmp, exch, tot, infl })
$$

Where $g d p$ is Gross Domestic Product as a proxy for economic growth;

exmp is the foreign exchange market demand pressure computed as the difference between the demand and supply of foreign exchange;

exch is the exchange rate;

tot is trade openness; and

infl is the rate of inflation.

The stochastic form of the model is expressed as follows:

$$
g d p=\beta_{0}+\beta_{1} \operatorname{exmp}+\beta_{2} \operatorname{exch}+\beta_{3} t o t+\beta_{4} i n f l+u \ldots \ldots \ldots \ldots \ldots \ldots \ldots \ldots \ldots \ldots .2
$$

Model 2 was estimated using the Autoregressive Distributed Lag (ARDL) technique. The Autoregressive Distributed Lag (ARDL) test procedure provides valid results whether the variables are $\mathrm{I}(0)$ or $\mathrm{I}(1)$ or mutually co-integrated, allows for simultaneous testing of the long-run and short-run relationships between the variables in a time series model and provides very efficient and consistent test results in small and large sample sizes (Pesaran \& Shin, 2001). 
Following the framework of the ARDL, model 4.2 can be specified as:

$$
\begin{aligned}
& \Delta g d p_{t}=\alpha_{0}+\sum_{i=1}^{p} \alpha_{1} \Delta g d p_{t-1}+\sum_{i=1}^{p} \alpha_{2} \Delta \operatorname{exmp}_{t-1}+\sum_{i=1}^{p} \alpha_{3} \Delta \operatorname{exch}_{t-1}+\sum_{i=1}^{p} \alpha_{4} \Delta t o t_{t-1}+ \\
& \sum_{i=1}^{p} \alpha_{5} \Delta i n f l_{t-1}+\varphi_{1} g d p_{t-i}+\varphi_{2} \operatorname{exmp}_{t-i}+\varphi_{3} \operatorname{exch}_{t-i}+\varphi_{4} \operatorname{tot}_{t-i}+\varphi_{5} \text { infl }_{t-i}+\varepsilon_{1 t}---- \\
& --4.3
\end{aligned}
$$

The error correction version of the ARDL model for equations 4.3 is presented as follows:

$$
\begin{aligned}
& \Delta g d p_{t}=\beta_{0}+\sum_{i=1}^{p} \beta_{1} \Delta g d p_{t-1}+\sum_{i=1}^{p} \alpha_{2} \Delta \operatorname{exmp}_{t-i}+\sum_{i=1}^{p} \alpha_{3} \Delta \operatorname{exch}_{t-i}+\sum_{i=1}^{p} \alpha_{4} \Delta t o t_{t-i}+ \\
& \sum_{i=1}^{p} \alpha_{5} \Delta \text { infl }_{t-i}+\emptyset E C M_{t-1}+\mu_{1 t} \ldots \ldots \ldots \ldots \ldots \ldots \ldots \ldots \ldots .4 .4
\end{aligned}
$$

Existence of a long-run relationship among the variables is examined by Bounds test. If the calculated F statistic is higher than the upper bound critical value, I (1) for the number of explanatory variables (k), the null hypothesis will be rejected. If the F statistic is lower than the lower bound critical value I (0), null hypothesis cannot be rejected. The F statistic being between I (0) and I(1) puts forth an indecision about co-integration among the variables under consideration.

The timeframe for this study span from 1986 to 2018 and the data were sourced from the CBN statistical bulletins of various years.

\section{Empirical Results}

\begin{tabular}{|c|c|c|c|c|c|c|c|}
\hline \multirow{4}{*}{ Variables } & \multicolumn{6}{|c|}{ Augmented Dickey-Fuller statistics of the variables } & \multirow{4}{*}{$\begin{array}{c}\text { Order of } \\
\text { Integration }\end{array}$} \\
\hline & \multirow{2}{*}{\multicolumn{2}{|c|}{ At Level }} & \multicolumn{4}{|c|}{ First Difference } & \\
\hline & & & \multirow[b]{2}{*}{ t-statistics } & \multicolumn{3}{|c|}{ Critical Values } & \\
\hline & ADF & $5 \%$ & & $1 \%$ & $5 \%$ & $10 \%$ & \\
\hline Gdp & -4.3855 & -2.9640 & -7.984218 & -3.679322 & -2.967767 & -2.622989 & $\mathrm{I}(1)$ \\
\hline Exmp & -2.9149 & -2.9640 & -5.627611 & -3.679322 & -2.967767 & -2.622989 & $\mathrm{I}(1)$ \\
\hline Exch & 0.8502 & -2.9640 & -3.449481 & -3.679322 & -2.967767 & -2.622989 & $\mathrm{I}(1)$ \\
\hline Tot & -1.9782 & -2.9640 & -5.814151 & -3.679322 & -2.967767 & -2.622989 & $\mathrm{I}(1)$ \\
\hline Infl & -4.1781 & -2.9981 & -4.780881 & -3.679322 & -2.967767 & -2.622989 & $\mathrm{I}(1)$ \\
\hline
\end{tabular}

The starting point of this analysis is the unit root testing, even though the ARDL technique does not require pretesting for unit root properties of the series, but the essence is to avoid series that are integrated of higher order. The result is presented in the following table.

Table 1: Unit Root Tests

Source: Researchers' Computation using Eview 9

The Unit root using Augmented Dickey-Fuller statistics shows that the variables are stationary at first difference since all the critical values at 5\% level of significance are greater than the t-statistics after differencing the series once. This means rejecting the null hypothesis of the existence of unit root in the series. The implication is that the series have mean reverting ability. That is, any shock to the series will fade away with passage of time.

Given the outcome of the unit root test, the bounds test co-integration was conducted and the results are shown in the following table; 
Table 2: Bounds Test Approach to Co-integration

Null Hypothesis: No long-run relationships exist

\begin{tabular}{lll}
\hline \hline Test Statistic & Value & $\mathrm{K}$ \\
\hline \hline F-statistic & 7.898243 & 4 \\
\hline \hline
\end{tabular}

Critical Value Bounds

\begin{tabular}{lcc}
\hline \hline Significance & I0 Bound & I1 Bound \\
\hline \hline $10 \%$ & 2.45 & 3.52 \\
$5 \%$ & 2.86 & 4.01 \\
$2.5 \%$ & 3.25 & 4.49 \\
$1 \%$ & 3.74 & 5.06 \\
\hline \hline
\end{tabular}

Source: Researchers' Computation using Eview 9

The result in Table 2 revealed that, the computed F-statistic value of 7.9 is greater than the upper bound value of 4.01 at $5 \%$ level of significance, which indicates that the variables are co- integrated i.e. there is a long-run relationship among the series under reference.

Considering the long-run relationship among the variables in the model, we continue to determine the long run coefficients as reported on Table 3.

Table 3: Long-run Coefficients

Dependent variable: gdp

\begin{tabular}{crrrr}
\hline \hline Variable & Coefficient & Std. Error & t-Statistic & Prob. \\
\hline \hline Exmp & -0.031114 & 0.012102 & -2.569310 & 0.0119 \\
Exch & 0.017223 & 0.032601 & 0.528293 & 0.6026 \\
Tot & 0.410571 & 0.333518 & 1.231030 & 0.2313 \\
Infl & -0.071665 & 0.011737 & -6.105918 & 0.0019 \\
C & 5.507734 & 5.121439 & 1.075427 & 0.2938 \\
\hline \hline
\end{tabular}

Source: Researcher's Computation using Eview 9

The long-run results of the ARDL model shows that the foreign exchange market demand pressure has an inverse relationship between with GDP and it is statistically significant at 5\% level of significance. This implies that as the demand for foreign exchange increases more the supply of foreign exchange, the GDP reduces by $3.11 \%$. This may be because of the import dependent nature of the Nigerian economy. Under normal circumstances, increase in demand for foreign exchange over its supply, is supposed to depreciate the naira and the depreciation is supposed to discourage import and encourage exports with attendant positive impact on the trade balance and consequently economic growth. However, in the context of the Nigerian economy, the demand and supply curves of the foreign exchange are inelastic such that they remain unresponsive to international price changes with its negative consequences on the GDP. The Nigerian economy exports majorly only the crude oil and imports large quantity of both consumable and capital goods, so depreciation of the naira occasioned by demand pressure in the foreign exchange market is rather disadvantageous to the economy.

Also, the ARDL long-run estimates have shown that inflation is negatively related with economic growth in Nigeria. The results depict that 1 per cent increase in inflation will reduce economic growth by 7.167 per cent. In Nigeria, foreign exchange market pressure even has the tendency of fueling inflation via the mechanism of exchange rate-pass to domestic prices. That is, when there is demand pressure in the foreign exchange market, the value of the Dollar will appreciate, while the value of the naira will depreciate. Thus, given the import dependent nature of the Nigerian economy, both the consumable goods and capital goods will be imported at higher prices leading to inflationary spiral in the country. 
Furthermore, the short-run estimates of the ARDL model were estimated and the result of the short-run is presented in Table 4.

Table 4: Short-run Estimates of the ARDL Model

Dependent Variable: gdp

\begin{tabular}{cccrr}
\hline \hline \multicolumn{6}{c}{ Cointegrating Form } & & \\
\hline \hline Variables & Coefficient & Std. Error & t-Statistic & Prob. \\
\hline \hline D(exmp) & -0.281213 & 0.032103 & -8.759712 & 0.0006 \\
D(exch) & -0.097430 & 0.076288 & -1.277134 & 0.2149 \\
D(tot) & 0.379534 & 0.302612 & 1.254192 & 0.2229 \\
D(infl) & -0.160011 & 0.055530 & -2.881589 & 0.0063 \\
ecm(-1) & -0.924405 & 0.201175 & -4.595030 & 0.0001 \\
\hline
\end{tabular}

$\mathrm{R}^{2}=0.59910$ Adj $\mathrm{R}^{2}=0.56393 \quad \mathrm{~F}$-Statistic $=9.193125$

Source: Researchers' Computation Using Eview 9

The short-run ARDL estimates also have confirmed that there is a negative relationship between foreign exchange market demand pressure and economic growth in Nigeria and there is a negative relationship between inflation and economic growth in Nigeria. This implies that demand pressure in the foreign exchange market can affect economic growth in Nigeria directly and indirectly via the exchange rate pass-through to domestic prices. The error correction term is rightly signed with a negative value and it is statistically significant, implying that any disequilibrium in the short-run between GDP and demand pressure in the foreign exchange market can be adjusted to equilibrium in the long-run.

The $\mathrm{R}^{2}$ adjusted value of 0.56393 implies that the explanatory variables included in the model have explained variations in the GDP of the Nigerian economy by $56.4 \%$; and the F-statistics value of 9.19 shows a good joint effect of the explanatory variables on the GDP of the Nigerian economy.

\section{Diagnostic Tests of the ARDL Model}

To confirm the reliability of our estimates, it is required that the diagnostic tests for the residuals should be in agreement with their respective null hypotheses. That is, the stochastic error term must be white noise with zero mean, constant variance and the successive values of the error term must be independent of each other. The results of the diagnostic tests are presented in Table 5.

Table 5: Diagnostic Tests of the ARDL Model

\begin{tabular}{|c|r|r|}
\hline Tests & Test-stat & Prob. \\
\hline Serial Correlation & (F-stat) & 0.2787 \\
\hline \multirow{2}{*}{ Heteroskedasticity } & 1.362660 & \\
\hline Normality & $($ F-stat) & 0.9965 \\
\hline
\end{tabular}

Source: Researchers' Computation using Eviews 9.

The result of the diagnostic tests presented in Table 5 indicate that the model has passed the tests for normality, Serial Correlation and heteroskedasticity at 5\% level of significance. The implication is that the model estimates are consistent, efficient and good estimators that could be relied upon for policy potency.

Furthermore, there is a need for the study to conduct a stability test of CUSUM and CUSUM square to test for the stability of the residuals and the estimates of the model. Thus, the plots are depicted in Figures 2 and 3 , respectively. 


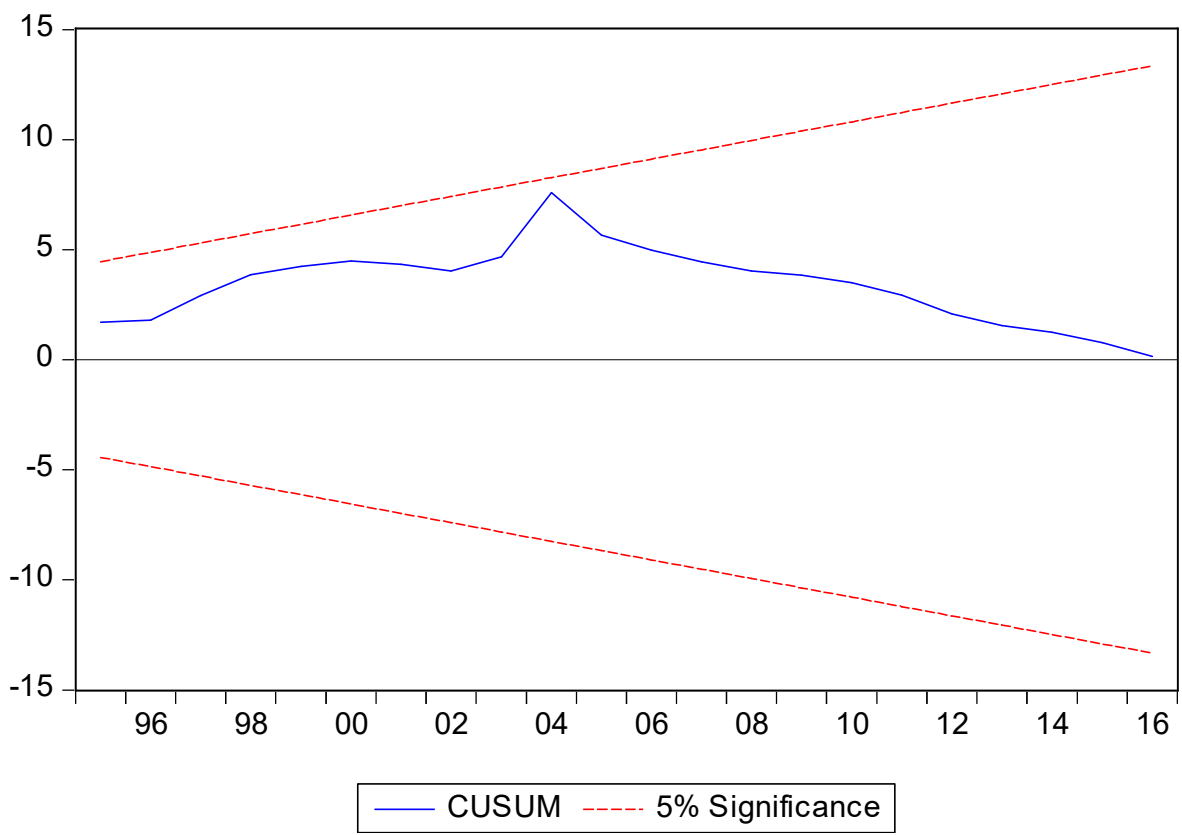

Figure 2: Plot of Cumulative Sum of Recursive Residuals

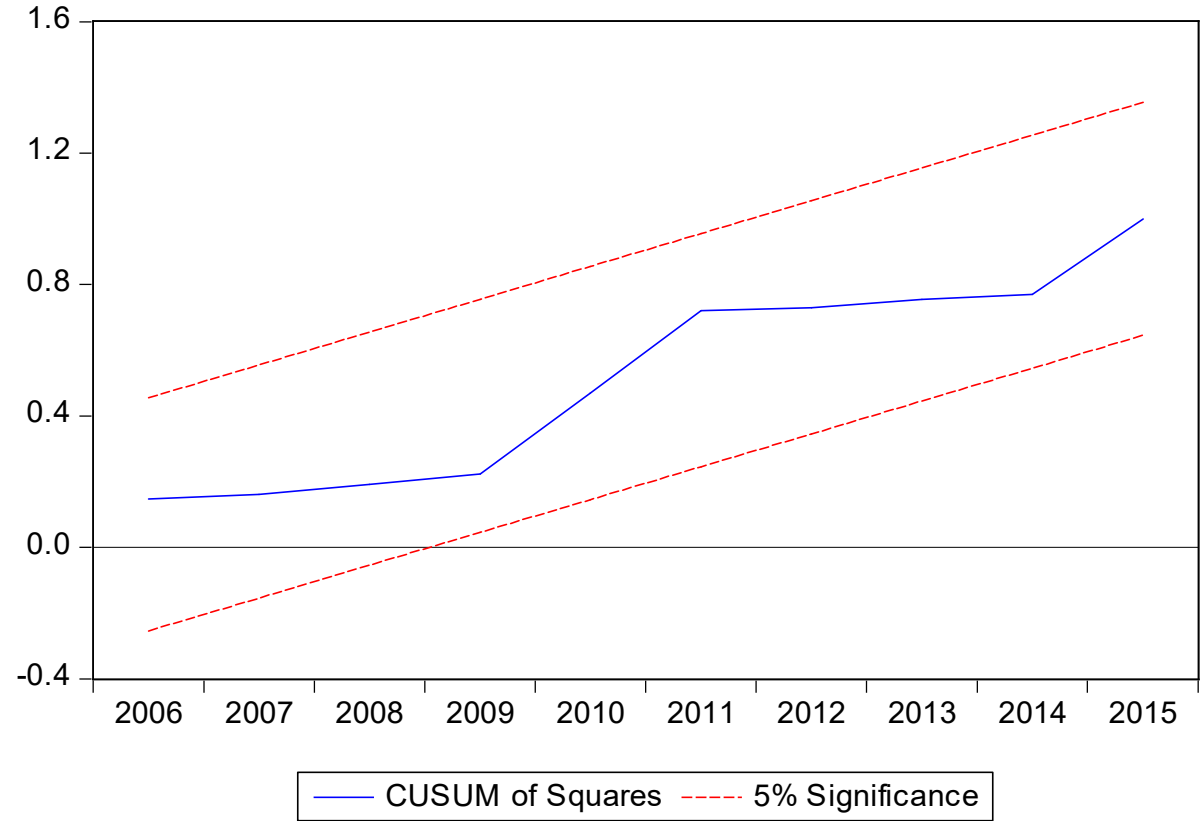

Figure 3: Plot of Cumulative Sum (squares) of Recursive Residuals

From the above plots of the CUSUM, it can be seen that the statistic is within the critical bounds region; suggesting the stability of the residual. This further justifies the fact that the estimates are consistent and reliable.

Pair Wise Granger Causality Test

The Granger causality test is used in determining the direction of causality among the variables under study. The result is presented in Table 6. 
Table 6: Granger Causality Test

\begin{tabular}{|c|c|c|c|}
\hline Null Hypothesis: & Obs & F-Statistic & Prob. \\
\hline EXMP does not Granger Cause GDP & 29 & 8.29171 & 0.0196 \\
\hline GDP does not Granger Cause EXMP & & 0.57046 & 0.5727 \\
\hline EXCH does not Granger Cause GDP & 29 & 11.46645 & 0.0028 \\
\hline GDP does not Granger Cause EXCH & & 0.29724 & 0.7456 \\
\hline TOT does not Granger Cause GDP & 29 & 1.63319 & 0.2163 \\
\hline GDP does not Granger Cause TOT & & 0.11750 & 0.8897 \\
\hline INFL does not Granger Cause GDP & 29 & 7.22364 & 0.02 \\
\hline GDP does not Granger Cause INFL & & 2.08298 & 0.1465 \\
\hline
\end{tabular}

Source: Researchers' Computation using Eview 9

The Granger causality results have shown that there exist a unidirectional causality running from Exchange market demand pressure (EXMP) to Gross Domestic Product. Also, a way causation is found to exist between inflation and economic growth in Nigeria; running from inflation to economic growth. The granger causality test has also re-enforced the findings from the ARDL model. Furthermore, exchange rate granger causes GDP in Nigeria. This means that exchange rate depreciation affects the economic growth process of the Nigerian economy.

\section{Policy Implication and Recommendations}

The policy implication of the relationship between foreign exchange market demand pressure and economic growth in Nigeria is that, foreign exchange market demand pressure affects economic growth in Nigeria directly and indirectly through the mechanism of exchange rate pass-through to domestic prices. Directly, when there is excess demand of foreign currency than its supply, the naira is put under pressure leading to the depreciation of the naira. The depreciation of the naira is supposed to discourage import and encourage exports with attendant positive impact on the trade balance and consequently economic growth. However, in the context of the Nigerian economy, the demand and supply curves of the foreign exchange are inelastic such that they remain unresponsive to international price changes with its negative consequences on the GDP. This is essentially because the Nigerian economy exports majorly only the crude oil which constitutes the major source of supply of foreign exchange to the economy and imports large quantity of both consumable and capital goods which on the other hand constitute the demand for foreign exchange in the country, so depreciation of the naira occasioned by demand pressure in the foreign exchange market is rather disadvantageous to the economy.

Indirectly, the foreign exchange market demand pressure affects economic growth via the mechanism of exchange rate pass-through to domestic prices. That is, when there is demand pressure in the foreign exchange market, as a result of shortages of supply of foreign exchange occasioned either by the slump in oil prices or reduction in its supply in the international market, the value of the Dollar will appreciate, while the value of the naira will depreciate. Thus, given the import dependent nature of the Nigerian economy, both the consumable goods and capital goods will be imported at higher prices leading to inflationary spiral in the country. These two effects combine to exert negative influence on the growth process of the Nigerian economy.

In view of these negative effects on the GDP of the Nigerian economy, this study has made the following recommendations; first, the Nigerian economy should be diversified away from oil using the agriculture and manufacturing sectors as articulated in the Economic Growth and Recovery Plan of the Buhari's administration. By diversification, multiple streams of supply of foreign exchange in the economy will be created to close the existing gap between its demand and supply in the country. Also, by diversification of the economy, the demand for imported goods will reduce. The reduction in the demand for imported goods into the country presupposes reduction in demand for foreign exchange. With this, the scarce foreign exchange can be conserved for only importation of capital goods for onward production of goods and services in the country.

Thirdly, the Central Bank should regulate the supply of foreign exchange to only critical sectors of the economy. The activities of the importers should also be checked to avoid cases of over invoicing and under invoicing. These activities generally lead to round-tripping with its adverse consequences on the demand and supply of foreign exchange in the country. 
References

Ailemen, O.I., Akhanolu, A.I., \& Chibuzor, I.O. (2016). Deregulation of Foreign Exchange Market and it Effect on Industrial Produce in Nigeria. Global Media Journal, SI:7.

Akanji, O. (2006). The Achievement of Convergence in the Nigerian Foreign Exchange Market. Central Bank of Nigeria (CBN) Bullion Vol.30, No.3.

Akpan, P.L. (2009). Foreign Exchange Market and Economic Growth in an Emerging Petroleum Based Economy: Evidence from Nigeria. African Economic and Business Review, http://dx.doi.org/10.2139.

Akram, G.M., \& Byme, J.P. (2015). Foreign Exchange Market Pressure and Capital Controls. Journal of International Financial Markets, Institutions and Money, 37, 42-53. DOI:10.1016.

Central Bank of Nigeria (2016). Foreign exchange market pressure. Research Department, Education in economics series, No.6.

Crocket, A. (1987). Exchange rate policy. In EDI, National Economic policy Making: The Key elements. Washinton, D.C: The World Bank.

Englama, A., Saani, H. T., Duke, O.O., Ogunleye, T.S. and Isma'il F.U. (2009). Determinants of demand pressure in Nigeria's foreign exchange market: An empirical analysis. CBN economic review, 47(2), 1-26

Fiador, V.O., \& Biekpe, N. (2015). monetary policy and exchange market pressure-evidence from sub-saharan Africa. Journal of Applied Economics, Vol. 47, No.37.

Garcia, M. \& Malet, N. (2005). Exchange Market Pressure, Monetary Policy and Economic Growth: Agentina in 1993-2004. Working papers. WP 99, Political economy research institute, university of Massachusetts at Amherst.

Mordi, C. (2006). Challenges of Exchange Rate Volatility in Nigeria in Economic Management in Nigeria. Central Bank of Nigeria (CBN) Bullion. Vol.30, NO.3.

Obadan, M. I. (2012). Foreign Exchange Market and the Balance of Payments: Elements, Policies and the Nigerian Experience. Benin,,Goldmark press,

Odusola, A. (2006). Economics of Exchange Rate Management. Central Bank of Nigeria Bullion Vol.30, No.3.

Okosodo, L.A., \& Imosili, S.A. (2012). The Deregulation of Foreign Exchange Market and its Impact on the Growth of the Nigerian Economy. ResearchersWorld-Journal of Arts, Science \& Commerce, Vol.111, 4(1).

Oladapo, F., \& Oloyede, J.A. (2014). Foreign Exchange Management and the Nigerian Economic Growth. European Journal of Business and Innovation Research, Vol.2, No.2, pp.19-31.

Oladele, A.R. (2015). Foreign Exchange Market and the Nigerian Economy. Journal of Economics and Sustainable Development, Vol.6, No.4.

Pesaran, M.H., Shin, Y. \& Smith, R.J. (2001). Bound Testing Approaches to the Analysis of Level Relationship. Journal of Applied Econometrics. Cambrige: John Willey \& Sons LTD. 